\title{
Alternative Control Measure for Reducing Citrinin and Alternariol in Broad Beans
}

\author{
N.H. Youssef ${ }^{2}$ and A.S.A.Saad ${ }^{1}$ \\ ${ }^{1}$ Faculty of Agriculture Saba Basha, Department of Plant Protection and Pesticides. \\ Alexandria University. \\ $\underline{{ }^{1} \text { Regional Central for Food and Feed. Alexandria, Agriculture Research Center, Egypt. }}$
}

\begin{abstract}
An environmental problem was recorded in broad bean crop cultivated in Noubareya region during season 2013. Harvested broad bean seeds were obtained by satisfactory evidence of weak economic value.

An attempt of seed treatment process was carried out in this study to inhibit fungal growth and mycotoxins produced by Alternaria alternata and Penicillium citrinum in field during cultivation process using sorbic and benzoic acids at 10 and 15 ppm,; ethyl sorbate and/or ethyl benzoate at 5 and $10 \mathrm{ppm}$ for each treatment as alternative to the fungicides metalaxyl DS and ridomil MZ72WP at recommended rate $(x)$ and $1 \frac{1}{2}$ recommended rate applied for seed protection during cultivation process.

The germination test showed the failure of all the tested preservative treatments to germinate seeds. Therefore; all treatments were used as foliar seedlings spray applied 3 times every 15 days during the experiment (60 days). The results of fungicidal activity indicated that the use of preservative up to $10 \mathrm{ppm}$ totally inhibited fungal growth except ethyl benzoate and ethyl sorbate which completely inhibited fungi at 5ppm Moreover, 5 and $10 \mathrm{ppm}$ concs realized the same inhibition rate exerted by metalaxyl and ridomil MZ at $1.5 \mathrm{x}$. Untreated plants showed higher death ratios, compared with treated ones. Ridomil MZ at conc. $1.5 \times$ reduced dead plants $60 \%$ followed by benzoic acid $56 \%$ at conc. 5 ppm. Furthermore, the ester form of both benzoic and sorbic acids were more effective in reducing AOH and CTN than the other tested fungicides. metalaxyl and ridomil $\mathrm{MZ}$ at $1.5 \mathrm{x}$. Ridomil $\mathrm{MZ}$ at conc. $1.5 \mathrm{x}$ reduced dead plants $60 \%$ followed by benzoic acid $56 \%$ at conc.5ppm. Furthermore, the ester form of both benzoic and sorbic acids acids were more effective in reducing altrnariol (AOH) and citrinin (CTN) than the other tested fungicides. Accordingly they can act successfully as fungicides alternatives.

Benzoic acid has been actively playing a great role as antifungal and detoxifier agent. Meanwhile, it affected plant growth which badly in need for more studies to avoid these side effects.
\end{abstract}

Key Words: Alternariol and citrinin detoxification, broad beans, Alternatives to ridomil MZ and metalaxyl, benzoic and sorbic acids.

\section{INTRODUCTION:}

Faba bean (Vicia fabae L.) is one of the most important food legumes due to its high nutritive value in terms of energy and protein contents (24-30\%),58\% carbohydrate and it is an excellent nitrogen fixer (El wakile et al., 2009). Egypt is the second largest producer of faba bean in the world, next to china (Torres et al., 2006a). The annual faba bean production in Egypt is ranging from 0.56 to 0.58 million metric ton during 2003-2005. However, this production is not enough to meet domestic demand (FLRP, 2004, ICARDA, 2005, Maalouf et al.,2009 and yehia et al .,2011). The first report concerning a new disease of faba bean crops which has been invaded by Alternaria tennuisina in Japan (Mohamed et al.,2002 and Barkai-Golan and Nachman,2008).

Alternaria alternata (Fr.) Keissler is a ubiquitous fungi and cause numerous plant diseases and many damages to crops in the field (Mašková et al.,2012). This facultative pathogen induces (spots and lesions) mainly on 
leaves and fruit and less severely on stolons and finaly leads to complete death of the plant. (El Morsi et al., 2006 and Vûckovíc et al.,2012). This disease was found in several countries and several plant crops (Bodroža-Solarov et al.,2012 and Vûckovíc et al.,2013). In addition to economic losses in production and processing (Kosiak et al., 2004), the disease lead to significant reduction in grain quality (Bodroža-Solarov et al., 2012) , this fungus produce AAL toxins (which means Alternaria alternata toxins) with different toxicological properties. The presence of these compounds in the food chain is an increasing concern for human and animal health due to their possible harmful effects. (Fern'andezCruz et al., 2010 and Burkin and Kononenko 2011).

There is a wide range of alternaria toxins but only few of them are associated with health risk acute toxicity (EFSA, 2011). AOH (alternariol) and $A M E(\underline{a l t e r n a r i o l ~ m o n o m e t h y l ~ e t h e r ~) ~ a r e ~ o f ~ t h e ~ m a j o r ~ c o n c e r n ~ s i n c e ~ t h e y ~ w e r e ~}$ found to have mutagenic, genotoxic and carcinogenic effects on mammalian cells (Battilani et al., 2009 and Bhaat et al.,2010).

Alternariol was detected in many agricultural commodities and other foodstuffs (Asam etal.,2010 and 2011, Malachova etal.,2011,Suchowilska et al.,2010, Vučković et al.,2012, Eckhout et al.,2013).

Both of Alternaria alternata and penicillium citrinum are not usually broad bean seeds invaders pathogens (Dixit and Singh).According to the available literature, this may be the first registration of this phenomena in Egypt suggesting the possibility to be a new patho-types.

Citrinin is acutely nephrotoxic at relatively high dose in mice and rats, rabbits, pigs and poultry causing swelling and eventual necrosis of the kidneys and affecting the liver function at a lesser extents (Abou-Zeid ,2012 and Friedman and Rasooly , 2013). There is no specific fungicides for controlling this crop disease case .However,many attempts in vitro are reported for inhibiting Alternaria alternata and Penicillium citrinum using metalaxyl and ridomil MZ (Javaid et al.,2006).

Metalaxyl: is used to control certain diseases caused by air-and soil-borne fungi. Foliar sprays with mixture of metalaxyl and protectant fungicides are recommended to control certain air-borne diseases.

Ridomil MZ 72 WP contains metalaxyl 8\% and mancozeb 64\%. Recently ShuYuan Cheng et al., 2014 demonstrated that mancozeb (MZ) induced cytotoxicity in rat pheochromocytoma (PC12) cells partially via nuclear factor kappa $B(N F-k B)$ activation. This study demonstrated that $M Z$ induced DNA damage as seen in comet assay.

Zeidan, (2006) reported that benzoic acid was applied on grapevine in Germanic green houses as MENNO-Florades (9\% benzoic acid) to antagonize Plasmopara viticola. This application realized highly antagonistic frequency $(91.40 \%)$, ( two days before fungal infection). 
Therefore, the aim of this study is to reduce the applied dose of fungicides by using preservatives and investigate their side effects on mycotoxins detoxification under field conditions.

\section{MATERIALS AND METHODS}

\section{Fungicides:}

Metalaxyl: (IUPAC) name: methyl N-(methoxyacetyl)-N-(2,6-xylyl)-D-alaninate. Ridomil MZ: methyl N-(methoxyacetyl)-N-(2,6-xylyl)-D-alaninate+ Mancozeb: manganese ethylene bis (dithiocarbamate) (polymeric) complex with zinc salt.

\section{Organic acid used as a food preservatives:}

Benzoic: $\mathrm{C}_{7} \mathrm{H}_{6} \mathrm{O}_{2}$ (or $\mathrm{C}_{6} \mathrm{H}_{5} \mathrm{COOH}$ ).

Sorbic acid, or 2,4-. hexadienoic acid: $\mathrm{C}_{6} \mathrm{H}_{8} \mathrm{O}_{2}$

\section{Structures of mentioned Mycotoxins:}

Alternariol is 3,7,9-Ttrihydroxy-1 methyl-6H-dibenzo[b,d] pyran-6-one.Its molecular formula $\mathrm{C}_{14} \mathrm{H}_{10} \mathrm{O}_{5}$.

Citrinin [ $\mathrm{C}_{13} \mathrm{H}_{14} \mathrm{O}_{51}$ ] IUPAC: (3R, 4s)-4,6- dihydro-8nhydroxy-3,4,5-trimethyl-6oxo-3H2- benzopyran-7-carboxylic acid.

The seed borne fungi associated with infected broad bean seeds collected from Noubaria region are previously isolated, purified and identified from surface sterilized seeds using seed health testing method and Frequency of the obtained fungi (Alternaria alternata ,Penicillium citrinum and Aspergillus flavus) was determined. Moreover, mycotoxin production ability was estimated and the occurred mycotoxins (alternariol and citrinin ) were detected and registered as mentioned in previous study (Youssef et al., 2014).

\section{Preparation of chemicals and organic acids serving in Agricultural Experiment:}

Benzoic and sorbic acids used as chemical or synthetic preservatives (Class II) are brought from Sigma, Aldrich, Bureau of Cairo Egypt. The food standards regulations required that not more than one Class II preservative should be used in one particular food item (Anand and Sati, 2013). Metalaxyl and ridomil $\mathrm{MZ}$ are brought from Syngenta Agro Egypt manufacturing.

\section{Agricultural experiment \\ Preliminary tests for agricultural experiment:}

It was necessary to test the performance of the used tested treatments on seed germination process, and fungal growth. The percent germination process was considered as the determining factor of how tested treatments will be applied during agricultural experiment either seed treatment before seeds Sown process or spraying seedling with the tested treatment every two weeks during the experiment (first test). Furthermore, it was necessary to determine the effect of these treatments on the growth of the occurred fungi associated with infected seeds (second test). 


\section{First test: Effects of the tested treatments on seed germination process .}

Untreated non infected seeds (Giza blanka) were brought from Research Seeds and Oily seeds Institute, Agricultural Researches Centre, Giza, Egypt. Germination viability test was carried out according to ISTA (1996), Singh and Garampalli, (2012) and Soughir et al., 2012 with certain modification. $100 \mathrm{~g}$ of seeds were taken from each healthy and/or infected seeds and divided into 5 replicates $-20 \mathrm{~g}$ each. Two fungicides metalaxyl and ridomil $M Z$ treatments are used at concentrations $0.5 \mathrm{x}, \mathrm{x}$ and $1.5 \mathrm{x}$ (where $\mathrm{x}=500 \mathrm{mg} / 250 \mathrm{ml}$ water). Benzoic and sorbic acids and their esters are used at concentrations 5, 10, 15 and $25 \mathrm{ppm}$. The effect of ethyl alcohol on germination process at concentration $0.25 \%$ was tested also. Seeds $(20 \mathrm{~g})$ in each treatment were placed in sterilized cup $125 \mathrm{ml}$ in volume, the tested concentration was added to sterilized distilled water $100 \mathrm{ml}$ to each cup for each treatment. The negative control for both healthy and infected healthy seed replicates comprise distilled sterilized eater treatment. Each cup solution was decanted 5 hours later, and then weighed. Seeds from each treatment were placed in 120-mm-diameter Petri dishes between two layers of Watman filter paper and then moistened with $10 \mathrm{ml}$ of distilled water for negative control, whereas, the other treatments were moistened with the same solution of the tested treatment. Seeds were kept at room temperature $\left(25^{\circ} \mathrm{C}\right)$ under normal light. The number of germinated seeds was counted daily for 7 days after which no further seed germination was occurred. The appearance of $2 \mathrm{~mm}$ or more of radical was considered as germination. Parameters measured in this experiment were registered:

Total germination (TG) measured in the seventh day using the formula GT (\%) $=$ (total number of germinated seeds $(B) /$ total seed $(A) \times 100$. ( Scott et al., 1984 and Moradi et al., 2008). The obtained data were registered in Table (1).

\section{Second test 2 :( Confirmation): Testing the treatments effect on growth of fungi occurred in seeds:}

The aim of this test was to determine the suitable concentrations for each treatment which will be applied during agriculture experiment. 15 seeds per replicate were taken then soaked in different concentrations of the tested fungicides and preservatives for 10 minutes. Healthy seeds for control were initially surface sterilized using sodium hypochlorite solution $5.0 \%$ for $3 \mathrm{~min}$. and then they were rinsed 3 times with distilled water for 2 min. (Soughir et al., 2012). For non infected and naturally infected control, the seeds were soaked in distilled water. Seeds of all the treatments were placed on filter papers in $9 \mathrm{~cm}$ diameter petri plates, moistened with $3 \mathrm{ml}$ of distilled water and/or tested treatment concentration each. Plates were incubated in a growth room at $25 \pm 2^{\circ} \mathrm{C}$ for 8days under alternative light and dark 12 hours each. Each treatment was replicated thrice (Christensen, 1957; Javaid et al., 2006 and Sitara and Hasan, 2011 with certain modification).

After 8 days of incubation, fungal species grown on the surface of treated seeds were purified and identified and their percentage frequency (PF) was determined according to Samson et al. (1996) and Javaid et al. (2006). The number of colonies growing on each plate was counted for each identified 
fungus and its frequency percentage was calculated according to the following formula (Pitt and Hocking, 1997):

$\mathrm{PF}=($ No. of seeds on which fungus appeared $/$ Total No. of seeds $) \times 100$

The resulted data were registered as shown in Table (2). The ability of the main occurred fungi was previously tested and detected as mentioned in precedent study (Youssef et al., 2014). The resulted data were registered as shown in Table (2). The selected treatment concentrations for agricultural experiment were summarized in Table (3).

\section{Agricultural experiment:}

The clay soil was used in this study ,the electrical conductivity(EC), in decisiveness per meter was measured by Baxter, Digital conductivity meter in saturated soil paste extract as described in hand book 60 (U.S Salinity Laboratory Staff, 1954). Acidity ( $\mathrm{pH}$ value) was also determined in the tested soil paste using $\mathrm{pH}$ meter.

Plastic pots containing $1.5 \mathrm{~kg}$ sterilized autoclaved clayey soil for $30 \mathrm{~min}$. and kept covered until sowing seeds. Both of healthy and infected seeds were surface sterilized using sodium hypochlorite $5 \%$ for $2 \mathrm{~min}$. Seeds were then rinsed three time in $100 \mathrm{ml}$ sterilized water each to completely get rid of sodium hypochlorite. Weighed seeds for 1 hour (10 seeds per pots) were carefully sown. Each treatment was replicated thrice. Pots were placed in complete sunny and fresh air weather to accomplish the field conditions. Seedlings of two weeks age are sprayed with tested treatments. The spraying process was applied and repeated fortnightly. At the end of the experiment, the number of dead plants was counted, measured as illustrated in Table (4), plants, 60 days age, were collected, washed then air dried. Plant fresh weight, root and shoot lengths and shoot black lesions lengths (for both dead and alive plants) were measured. Data were registered as illustrated in Table (5).

\section{Estimation of the inhibitory effect of treatments on plant contents of alternariol $(\mathrm{AOH})$ and citrinin (CTN):}

The main target of this experiment was to achieve the best treatment which reduce or prevent the production of the two tested mycotoxins during agriculture experiment (in vivo) under field conditions. Moreover, this experiment was aimed too to study the following:-The transition of alternariol $(\mathrm{AOH})$ and citrinin (CTN ) during the agricultural process from sown seeds to plant; and the effectiveness of the applied spraying method in reducing the two tested mycotoxins.

Plants in each treatment were gently cut into small pieces, and then puted in sterilized cups $10 \mathrm{~g}$ each. Treatments were triplicated. Plant samples were prepared to be detected firstly by using TLC ( Thin layer chromatography) plate 
(Jouany, 2007 and Kütt et al., 2010).Two development systems were used for each toxin: Anis: $0.5 \% \mathrm{p}$-anisaldehyde in methanol/acetic acid/conc; and sulphuric acid (17:2:1v/v/v) for alternariol and benzene: glacial acetic acid: acetone (5:4:1) v/v/v (Frisvad et al. 2007 and Eckhout et al., 2013). Under UV light at $254 \mathrm{~nm} \mathrm{AOH}$ was detected whereas, CTN was detected at $366 \mathrm{~nm}$. After that the detection of alterniol (alternariol) and citrinin was confirmed by using quantitatively HPLC-UV technique according to Azcarat et al., (2008), Asam et al. ,2011) and Brzonkalik et al., (2011) at Central Lab, Faculty of Pharmacy, Alexandria University. The obtained citrinin and alternariol standards were brought from Sigma, Aldrich ,Cairo, Egypt. Results were registered in Table (4).

\section{Statistical analysis:}

The experiment was laid out in completely randomized design with three replications. The data were subjected to statistical analysis using Costat computer package (CoHort Software, Berkeley, CA, USA). Least significant difference (LSD) using Duncan's Multiple Range test was applied to compare the treatment mean values according to McDonald, (2009).

\section{RESULTS AND DISCUSSION}

\section{2. a. Determination of the Electric conductivity and $\mathrm{pH}$ in soil used in the experiment.}

The applied soil was sterilized before planting and soil electrical conductivity (EC) and $\mathrm{pH}$ degree were determined. $\mathrm{EC}$ of the soil paste was 3.4 $\mathrm{dS} / \mathrm{m}$, whereas soil $\mathrm{pH}$ was 7.5 .

\section{2. b. Tested treatments effects on seed germination process .}

The germination viability of seeds under treatments concentration was tested. Resulted data as illustrated in Table (1) indicated the following: The number of seeds in the same weight varied according to fungal infection. Furthermore, the degree of infection varied between seeds in the same yield. Germination process was affected by fungal infection, the average of germinated seeds attained the highest value at metalaxyl at recommended dose $(x)$ and ridomil $M Z$ at $(1 / 2 x)$.

Retardation in germination was observed during treatment with ethyl alcohol $25 \%$, but it was completely inhibited and delayed in treatments, treated with the tested preservatives and their esters. Fungal infection reduced seed germination rate. These findings were totally in harmony with those reported by Embaby et al. (2013) and Perelló and larrán (2013). These results limited the mode of treatments application as seedling spraying method. Both of benzoic and sorbic acids and their esters failed to be applied as seed treatment. Our results are completely in agreement with those of Maouni et al. (2002), Sitara and Akhter (2007), Saleem et al. (2012) and Sarmamy and Khidir, (2013), who reported that ridomil $M Z$, ridomil $M Z$ gold and metalaxyl increased seed germination percentages. Moreover, results obtained by benzoic acid and other alternatives were totally in agreement with Sunaina and Singh ,2014) and indirectly coincided with those of Yadav and Singh (2013), who reported that 
benzoic acid (BA) decreases the germination ratio of Triticum aestivum $\mathrm{L}$. sown in pots containing concentrations $(0.5,1$ and $1.5 \mathrm{mM})$ of $B A$ in dose dependent manner. Maximum 37.5\% reduction in germination was recorded at highest concentration of BA. In our study benzoic, sorbic acids and their esters completely failed in germination process. Differences may be attributed to differences in seeds cultivars, and s the applied method. In our experiment, faba bean seeds were completely emerged in aqueous solution in treatment left for $5 \mathrm{~h}$. before decanting water then placed between two filter papers imbibed with the tested treatment concentration. Thus, the treatment was entirely available for seeds, whereas in Yadav and Singh experiment (2013), seeds were sown in soil containing high concentration of benzoic acid each but undoubtly, the bioavailability of treatment in aqueous media is different than soil because soils can absorb this acid, consequently reduce the treatment bioavailability to seeds. Our findings were also in compatible with those reported by Deepavali and Nilima ,(2012), who reported that aflatoxin decreases germination rate.

\section{Second test: Inhibitory Effect of the treatments on fungal growth of seed flora:}

The effects of the tested treatments on growth of fungal seed flora were confirmed. Treatments have inhibitory effects against Alternaria alternata, Penicillium citrinum, Aspergillus flavus, Penicillium sp and Aspergillus niger. Results were registered as elucidated in Table (2).

Metalaxyl had moderate inhibition against $A$. alternata, but increased the Penicillium citrinum growth. Our findings were highly in accordance with those of Cohen, (1981), who found that metalaxyl enhanced the penicillium growth in citrus fruits. Our results were also harmoniously compatible with those of Matheron and Porchas (2000) and Saleem et al. (2012), who reported that metalaxyl $15 \%$ + copper oxychloride and ridomil MZ (metalalaxyl+mancozeb) exhibited a satisfied inhibitive effect against A.alternata and P.expansum. According to results obtained in the present investigation and those reported by others, chemicals added to metalaxyl such as copper oxychloride or mancozeb ameliorate augmented the inhibitory effect of these mixture against Penicillium than metalaxyl alone.

\section{Agricultural experiment:}

\subsection{Determination of death rate:}

The aim of this test is to determine the effect of fungal infection on plant death and investigate the effects of the tested treatments on reducing death rate. Data in Table (4) illustrated that ridomil MZ at conc. $1.5 \times$ realized the best results in maintained plant life under fungal infection conditions, followed by benzoic acid at 10 ppm. Sorbic acid at conc. 10 ppm and its ester form revealed approximately the same action. These findings were partially in harmony with Hawthorne et al. (2014), who reported that mancozeb (750-800 g/kg) significantly suppressed Alternaria spp growth, compared with the other tested fungicides. Similarly, the findings of the same authers may also explain our second finding concerning the worth treatment in maintained plant life enhanced 
by metalaxyl and ridomil $\mathrm{MZ}$ at their recommended dose. This notice may also indicated that these recommended doses were applied only for healthy seed and plant protections but not for actually occurred infection treatment. Death rate in untreated infected plant was extremely high. Our findings are harmoniously agreed with those of Perelló and larrán (2013), who reported that Alternaria not only reduces germination and vigor of wheat seed but it also causes seedling blight disease in Argentina (Rajput et al., 2005 and Perelló, $2010 \mathrm{a}$ and $\mathrm{b}$ ) its transmission from seed to seedling of wheat seeds has been done in Argentina. Moreover, every year this seed-borne fungi cause heavy yield loss of the crop. 
Table (1): Comparing between the influence of certain fungicides, organic acids and esters on germination process of broad bean seeds

\begin{tabular}{|c|c|c|c|c|c|c|}
\hline \multicolumn{2}{|c|}{ Treatment } & \multirow{2}{*}{$\begin{array}{c}\text { T.S.N/W } \\
\text { For 5replicate } \\
\text { (A) } \\
98 \mathrm{i}\end{array}$} & \multirow{2}{*}{$\begin{array}{c}\text { Tested } \\
\text { conc. } \\
0.0\end{array}$} & \multirow{2}{*}{$\begin{array}{c}\begin{array}{c}\text { Average of } \\
\text { Germinated seed } \\
\text { number (B) }\end{array} \\
56 f\end{array}$} & \multirow{2}{*}{$\begin{array}{c}\text { Day at } \\
\text { G start }\end{array}$} & \multirow{2}{*}{ 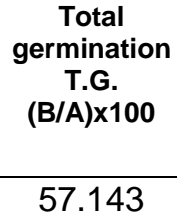 } \\
\hline & Healthy control & & & & & \\
\hline \multirow[t]{2}{*}{ Control } & Infected control & $138 b$ & 0.0 & $68 d$ & $4 b c$ & 49.275 \\
\hline & Healthy +alcohol & $97 i$ & $0.25^{\star}$ & $55 f$ & $6 a$ & 56.701 \\
\hline Inf. seeds & +Metalaxyl & $135 \mathrm{c}$ & $\mathrm{X}$ & $120 a$ & $3 \mathrm{~cd}$ & 88.89 \\
\hline \multirow{5}{*}{$\begin{array}{l}\text { Infected seeds } \\
+ \text { Fungicides }\end{array}$} & +Metalaxyl & $130 \mathrm{~g}$ & $1 / 2 X$ & $110 \mathrm{c}$ & $4 \mathrm{bc}$ & 81.48 \\
\hline & + Metalaxyl & $125 \mathrm{~h}$ & $1 \frac{1}{2} X$ & $65 \mathrm{e}$ & $5 a b$ & 52.00 \\
\hline & +Ridomil MZ & $130 \mathrm{~g}$ & $X$ & $115 b$ & $2 d$ & 88.46 \\
\hline & +Ridomil MZ & 145ef & $1 / 2 X$ & $120 a$ & $3 \mathrm{~cd}$ & 82.76 \\
\hline & +Ridomil MZ & $130 \mathrm{~g}$ & $11 / 2 X$ & $115 b$ & $2 e$ & 88.46 \\
\hline \multirow{8}{*}{$\begin{array}{l}\text { Infected seeds } \\
\text { +organic acids } \\
\text { +Sorbic acid }\end{array}$} & +Benzoic acid & $132 \mathrm{~cd}$ & $5 p p m$ & $0.0 \mathrm{~g}$ & Oef & 0.0 \\
\hline & +Benzoic acid & 134de & $10 p p m$ & $0.0 \mathrm{~g}$ & Oef & 0.0 \\
\hline & +Benzoic acid & $130 \mathrm{~g}$ & $15 p p m$ & $0.0 \mathrm{~g}$ & Oef & 0.0 \\
\hline & +Benzoic acid & $135 \mathrm{c}$ & $25 p p m$ & $0.0 \mathrm{~g}$ & Oef & 0.0 \\
\hline & +Sorbic acid & $135 \mathrm{c}$ & $5 p p m$ & $0.0 \mathrm{~g}$ & Oef & 0.0 \\
\hline & +Sorbic acid & $130 \mathrm{~g}$ & $10 p p m$ & $0.0 \mathrm{~g}$ & Oef & 0.0 \\
\hline & +Sorbic acid & $132 \mathrm{~cd}$ & $15 p p m$ & $0.0 \mathrm{~g}$ & Oef & 0.0 \\
\hline & +Sorbic acid & $132 \mathrm{~cd}$ & $25 p p m$ & $0.0 \mathrm{~g}$ & Oef & 0.0 \\
\hline \multirow{9}{*}{$\begin{array}{l}\text { Infected seeds } \\
+ \text { Esters }\end{array}$} & +Ethyl benzoate & $130 \mathrm{~g}$ & $5 p p m$ & $0.0 \mathrm{~g}$ & Oef & 0.0 \\
\hline & +Ethyl benzoate & $125 \mathrm{~h}$ & $10 p p m$ & $0.0 \mathrm{~g}$ & Oef & 0.0 \\
\hline & +Ethyl benzoate & $132 \mathrm{~cd}$ & $15 \mathrm{ppm}$ & $0.0 \mathrm{~g}$ & Oef & 0.0 \\
\hline & +Ethyl benzoate & 145 ef & $25 p p m$ & $0.0 \mathrm{~g}$ & Oef & 0.0 \\
\hline & +Ethyl sorbate & 134de & $5 p p m$ & $0.0 \mathrm{~g}$ & Oef & 0.0 \\
\hline & +Ethyl sorbate & $133 c d$ & $10 p p m$ & $0.0 \mathrm{~g}$ & Oef & 0.0 \\
\hline & +Ethyl sorbate & $135 c$ & $15 p p m$ & $0.0 \mathrm{~g}$ & Oef & 0.0 \\
\hline & +Ethyl sorbate & $131 \mathrm{fg}$ & $25 \mathrm{ppm}$ & $0.0 \mathrm{~g}$ & Oef & 0.0 \\
\hline & L.S.D.0.50 & 1.4297 & & 1.8842 & 1.2272 & \\
\hline
\end{tabular}

\section{Where:}

- T.S.N $/$ W/5replicate $=$ Total seed number in $20 \mathrm{~g}$ seeds per 1 replicate.

${ }^{*}=$ ethyl alcohol concentration-

- used $=1: 4$ sterilized de-ionized water.

${ }^{* *}=$ The germination process started later than the other treatments.

$\mathrm{X}=$ recommended dose for application

(R.D) $=0.5 \mathrm{~g} / 250 \mathrm{ml}$ water)

G start = day in which seed start to germinate.

H. seeds $=$ non infected seeds.

Inf.seeds=infected seeds 
Table (2): Effect of the tested treatments on fungal inhibition

\begin{tabular}{|c|c|c|c|c|c|c|c|c|c|}
\hline \multirow{3}{*}{ Treatment } & \multirow{3}{*}{ Conc. } & \multicolumn{6}{|c|}{ Number of colonies formed per 15 seeds for each replicate } & \multirow{3}{*}{ Tot.Fr. } & \multirow{3}{*}{$\begin{array}{l}\text { Inhib. } \\
\text { ER \% }\end{array}$} \\
\hline & & \multicolumn{2}{|c|}{ A. alternata } & \multicolumn{2}{|c|}{ P.citrinum } & \multicolumn{2}{|c|}{ Other fungi } & & \\
\hline & & & Freq\% & & Freq\% & & Freq\% & & \\
\hline Healthy seeds & 0.0 & 0.0 & 0.0 & 0.0 & 0.0 & $6+2^{*}$ & $10.67^{*}$ & 10.67 & \\
\hline Infected seeds(I.S) & 0.0 & 58 & 77.34. & 12 & 16.0 & 5 & $6.67^{* *}$ & 100.01 & 0.0 \\
\hline I.S.+Ethyl alcohol & $0.25 \mathrm{ml}$ & 56 & 74.667 & 12 & 16 & 7 & $9.334^{* *}$ & 99.651 & 0.448 \\
\hline +metalaxyl & $1 / 2 X g / m l$ & 32 & 71.12 & 16 & 21.33 & $2.0^{\star *}$ & $2.667^{*}$ & 95.116 & 4.979 \\
\hline + metalaxyl & $\mathrm{Xgm} / \mathrm{ml}$ & 8 & 10.667 & 10 & 13.33 & $2.0^{* *}$ & $2.667^{*}$ & 26.664 & 73.363 \\
\hline +metalaxyl & $11 / 2 \mathrm{Xgm} / \mathrm{ml}$ & 5 & 6.667 & 4 & 5.333 & 0.0 & 0.0 & 12.334 & 87.678 \\
\hline +ridomil MZI & $1 / 2 \mathrm{Xgm} / \mathrm{ml}$ & 7 & 9.333 & 10 & 13.33 & 0.0 & 0.0 & 22.663 & 77.736 \\
\hline +ridomil MZ & $\mathrm{Xgm} / \mathrm{ml}$ & 5 & 6.667 & 7 & 9.333 & 0.0 & 0.0 & 16.0 & 84.402 \\
\hline +ridomil MZ & $11 / 2 \mathrm{Xgm} / \mathrm{ml}$ & 1 & 1.33 & 3 & 4.000 & 0.0 & 0.0 & 5.33 & 94.675 \\
\hline +benzoic acid & $5 p p m$ & 0.0 & 0.0 & 11 & 14.66 & $2^{* *}+2^{*}$ & 5.33 & 19.99 & 80.029 \\
\hline +benzoic acid & 10ppm & 0.0 & 0.0 & 10 & 13.33 & $2^{* *}$ & 2.667 & 15.996 & 84.019 \\
\hline +benzoic acid & 15ppm & 0.0 & 0.0 & 0.0 & 0.0 & 0.0 & 0.0 & 0.0 & 100.0 \\
\hline +benzoic acid & 25ppm & 0.0 & 0.0 & 0.0 & 0.0 & 0.0 & 0.0 & 0.0 & 100.0 \\
\hline +sorbic acid & 5ppm & 0.0 & 0.0 & 5.0 & 6.667 & 0.0 & 0.0 & 6.667 & 93.34 \\
\hline +sorbic acid & 10ppm & 0.0 & 0.0 & 2.0 & 2.667 & 0.0 & 0.0 & 2.667 & 97.34 \\
\hline +sorbic acid & 15ppm & 0.0 & 0.0 & 0.0 & 0.0 & 0.0 & 0.0 & 0.0 & 100.0 \\
\hline +sorbic acid & 25ppm & 0.0 & 0.0 & 0.0 & 0.0 & 0.0 & 0.0 & 0.0 & 100.0 \\
\hline + Ethyl benzoate & $5 p p m$ & 0.0 & 0.0 & 0.0 & 0.0 & 0.0 & 0.0 & 0.0 & 100.0 \\
\hline +Ethyl benzoate & 10ppm & 0.0 & 0.0 & 0.0 & 0.0 & 0.0 & 0.0 & 0.0 & 100.0 \\
\hline + Ethyl benzoate & 15ppm & 0.0 & 0.0 & 0.0 & 0.0 & 0.0 & 0.0 & 0.0 & 100.0 \\
\hline+ Ethyl benzoate & 25ppm & 0.0 & 0.0 & 0.0 & 0.0 & 0.0 & 0.0 & 0.0 & 100.0 \\
\hline + Ethyl sorbate & 5ppm & 0.0 & 0.0 & 0.0 & 0.0 & 0.0 & 0.0 & 0.0 & 100.0 \\
\hline + Ethyl sorbate & 10ppm & 0.0 & 0.0 & 0.0 & 0.0 & 0.0 & 0.0 & 0.0 & 100.0 \\
\hline +Ethyl sorbate & 15ppm & 0.0 & 0.0 & 0.0 & 0.0 & 0.0 & 0.0 & 0.0 & 100.0 \\
\hline +Ethyl sorbate & 25ppm & 0.0 & 0.0 & 0.0 & 0.0 & 0.0 & 0.0 & 0.0 & 100.0 \\
\hline
\end{tabular}

Where: $8^{*}=6$ colonies of Penicillium sp and 2 colonies of Aspergillus niger \& PF $=$ Frequency percentage of each fungal $\mathrm{sp} . \& 2^{*}+2^{\star *}=2^{*} P e n i c i l l i u m$ sp colonies + $2^{* \star}$ A.flavus colonies \& $\quad{ }^{* *}=$ A.flavus colonies 
Our selected treatments are summarized as shown in Table (3)

Table(3): Treatment concentrations applied in the Agricultural experiment.

\begin{tabular}{ccc}
\hline Treatment & Used Tested concentration & Efficacy ratio \% \\
\hline Metalaxyl & $\mathrm{Xgm} / \mathrm{ml}$ & $73.363(\mathrm{R} . \mathrm{D})$ \\
Metalaxyl & $11 / 2 \mathrm{Xgm} / \mathrm{ml}$ & 87.678 \\
Ridomil $\mathrm{MZ}$ & $\mathrm{Xgm} / \mathrm{ml}$ & $84.402(\mathrm{R} . \mathrm{D})$ \\
Ridomil $\mathrm{MZ}$ & $11 \frac{\mathrm{Xgm} / \mathrm{ml}}{94.675}$ \\
Benzoic acid & $10 \mathrm{ppm}$ & 84.019 \\
Benzoic acid & $15 \mathrm{ppm}$ & 100.0 \\
Sorbic acid & $10 \mathrm{ppm}$ & 97.336 \\
Sorbic acid & $15 \mathrm{ppm}$ & 100.0 \\
\hline
\end{tabular}

Table (4): effect of the tested treatments on reducing plant death:

\begin{tabular}{lccc}
\hline \multicolumn{1}{c}{ Treatments } & Death rate \% & $\begin{array}{c}\text { AV.of Number of dead } \\
\text { Seedlings(per 18seeds) } \\
\text { for each replicate }\end{array}$ & $\begin{array}{c}\text { Reduction ratio } \\
\text { in death rate\% }\end{array}$ \\
\hline Healthy control & 11.12 & $2 \mathrm{~g}$ & - \\
Infected control & 94.45 & $17 \mathrm{a}$ & - \\
Metalaxyl $(\mathrm{x})$ & 88.89 & $16 \mathrm{a}$ & 5.56 \\
Metalaxyl $(1.5 \mathrm{x})$ & 88.89 & $16 \mathrm{a}$ & 5.56 \\
Ridomil MZ $(\mathrm{x})$ & 88.89 & $16 \mathrm{a}$ & 5.56 \\
Ridomil MZ $(1.5 \mathrm{x})$ & 33.34 & $6 \mathrm{f}$ & 61.11 \\
Ethyl benzoate $(5 \mathrm{ppm})$ & 66.67 & $12 \mathrm{bc}$ & 27.78 \\
Ethyl benzoate $(10 \mathrm{ppm})$ & 72.22 & $13 \mathrm{~b}$ & 22.23 \\
Ethyl Sorbate $(5 \mathrm{ppm})$ & 50.56 & $10 \mathrm{~cd}$ & 43.89 \\
Ethyl Sorbate $(10 \mathrm{ppm})$ & 50.0 & $9 \mathrm{de}$ & 44.45 \\
Benzoic acid 10ppm & 38.89 & $7 \mathrm{ef}$ & 56.0 \\
Benzoic acid 15ppm & 50.0 & $9 \mathrm{de}$ & 44.45 \\
Sorbic acid 10ppm & 50.56 & $10 \mathrm{~cd}$ & 43.89 \\
Sorbic acid 15 ppm & 61.12 & $11 \mathrm{bcd}$ & 33.33 \\
\hline L.S. $\mathrm{D}_{0.05}$ & & 2.6944 & \\
\hline
\end{tabular}

\subsection{Effects of the tested treatments on certain plant growth parameters:}

Seedling shoot and root lengths, plant fresh weight, black color lesion $(B C L)$ on faba bean seedling shoots were determined. BCL ratio was calculated for each treatment to assess the effects of the tested treatments on curing infected seedlings. Data in Table (4) illustrated that fungal infection significantly reduced all plant growth parameters and realized the highest BCL values, which indicated the relation between BCL produced by these pathogens and their virulence in field. These findings were in harmony with Yamaji et al. (2001); Khan et al. (2008) and Hawthorne et al. (2014). 
Our results concerning the effect on shoot length revealed that Ridomil MZ realized the two highest shoot lengths, followed by ethyl benzoate at conc.5 ppm then ethyl sorbate. Metalaxyl and benzoic acid decreased shoot length These findings were in agreement with Wandrey et al. (2004), who mentioned that metalaxyl affected plant growth and plant height only when was applied as spraying. Moreover, these results coincided with those reported by Maffei et al. (1999); Yadav and Singh (2013) and Sunaina and Singh (2014), who reported that benzoic acid (BA) significantly decreased plant growth and seed germination proportionally with the increase in concentration.

Concerning root length, ethyl benzoate, ethyl sorbate at 5 ppm and sorbic acid at $10 \mathrm{ppm}$ realized the best same action as ridomil $\mathrm{MZ}$ at $1.5 \mathrm{X}$ on root length. In contrast to that, metalaxyl, benzoic acid and sorbic acid at $10 \mathrm{ppm}$ achieved the worth results. These results are partially in agreement with Magarey et al. (1995 and 1997) and Matheron and Porchas (2000), who mentioned that mancozeb ameliorate root and shoot growth than metalaxyl and were in harmony with those of Fujita and Syono (1996), who reported that the extent of inhibition of root growth by benzoic acid at $10 / \mu \mathrm{M}$ in pir2-I and pir2-I auxl-7 seedlings was $44 \%$ and $19 \%$, respectively as compared with control in absence of benzoic acid (BA) without any inhibition of polar auxin transport (Hertel et al., 1969 and 1983). On the other hand, Kim and Roh (2014) reported that BA appeared to promote the growth of tobacco plants. The best growth was obtained on day 50, but the activity of the antioxidative enzyme (glutathione reductase) was inhibited, which suggested that faba bean plant is less resistant to BA than tobacco plants.

Seedling fresh weight determinations :both of ethyl benzoate (5ppm) and sorbic acid (10ppm) realized similar effects as ridomil $M Z(1.5 x)$ on seedling fresh weight. Our findings were in agreement with those of Magarey and Bull (1994) and Saleem, (2010), who reported that mancozeb augmented shoot and root dry weight of sugarcane. Furthermore, Magarey and Croft (1995) reported that metalaxyl reduced shoot and root dry weight. Moreover, Magarey and Bull (2003) found that mancozeb caused yield decline in affected soil.

Black color lesions (BCL) attained the highest values in case of infected untreated seedlings and was absent in uninfected seedlings. These results indicated that the existence of this phenomenon was completely correlated to phytopathogenicity and plant diseases. According to many literatures, the seedling infection with Alternaria alternata or Penicillium citrinum do not produce these large black color lesions but the last one appeared when the double infection with both fungus occurred. Thus, it is suggested the presence of a synergistic effect between the two last mentioned fungi which appeared strongly on BCL production is a sort of virulent phytopathogenisty. Our findings are coincided with those of Perello et al. (2005, 2008 and 2012 and Benssassi et al. (2009).

Treatment's effectiveness rank was as the following: ethyl benzoate at $5 \mathrm{ppm}>$ benzoic acid at $10 \mathrm{pm}>$ ridomil $\mathrm{MZ}$ at $1.5 \mathrm{x}>$ sorbic acid at $10 \mathrm{ppm}$ then 
ethyl sorbate at 5ppm. Both of benzoic and sorbic acids at $15 \mathrm{ppm}$ had approximately the same efficiency of metalaxyl $x$.

\subsection{Effect of the tested fungicides and their alternative preservatives on alternariol (AOH) and citrinin (CTN) inhibition in obtained plants after agriculture process.}

This experiment was carried out on plants collected and prepared for mycotoxins estimation as mentioned above and data were registered and illustrated as shown in Table (5).

Concerning transition of $\mathrm{AOH}$ and CTN during the agriculture process from sown seeds to plant, according to Youssef et al. (2014), the average of seeds mycotoxins contents in non-treated seeds were $231.00 \mu \mathrm{g} / \mathrm{gm}$ for $\mathrm{AOH}$ and $337.00 \mu \mathrm{g} / \mathrm{g}$ for CTN (Table 6). It was remarked that during agriculture process both of the tested mycotoxins were transmitted from infected seeds to infected plants containing 219.739 and $250.950 \mu \mathrm{g} / \mathrm{g}$ in $\mathrm{AOH}$ and CTN, respectively. These findings are coincided with those of Muller and Amend (1997) and Perelló and larrán (2013), who suggested that the decline in mycotoxins degradation in plant was resulted from the exhaustion of nutrients lowering the mycotoxin production rate. Furthermore, our results are compatible with those of Miller et al., 1983 and Bhatnagar et al. (1991), who hypothesized that the biological degradation of mycotoxins in plant is an enzymatic degradation which considered the plant as source of these enzymes. Lugauskas, (2005) mentioned that $\mathrm{AOH}$ and CTN need a sort of fermentation to be degraded.

The efficiency of the tested treatment in inhibiting or reducing $\mathrm{AOH}$ and CTN during agriculture process: Ethyl benzoate at conc.10 ppm was the best treatment, where complete inhibition of $\mathrm{AOH}$ and CTN production, followed by the concentration $5 \mathrm{ppm}$ then ethyl sorbate at $10 \mathrm{ppm}$ and benzoic acid at 10 and15 ppm, followed by sorbic acid at $15 \mathrm{ppm}$. Metalaxyl at its recommended dose has a strong inhibitory effects on CTN only but ridomil MZ has a quite effects on both toxins. The inhibition rate was reversely proportional to concentration in ridomil $\mathrm{MZ}$. These findings were reasonably compatible with those of Abd-El Ghany and Tayel (2009), who reported that fungal growth inhibition was sometimes inversely proportional to mycotoxin inhibition .In contrast to that, sorbic acid at $10 \mathrm{ppm}$ has an effective inhibitory effects on CTN and moderately effect on $\mathrm{AOH}$.

The effectiveness of the applied spraying method in reducing the two tested mycotoxins: According to our obtained results, the applied spraying method during this experiment was very satisfactory effective in reducing the two tested mycotoxins. This explained its success in making the pre-harvest crop's yield safety for both human and animal consumption and the plant commodities too.

According to Table (5) and (6) we can notice that in case of $\mathrm{BCL}, \mathrm{AOH}$ and CTN inhibitions, ethyl benzoate had the inhibitoriest effect. It can be suggested

Vol. 20(1), 2015 
that both mycotoxins are involved in BCL appearance and phytotoxity. Such explanation was in agreement with those of Wang (1948); Nickell and Finlay (1954); White and Truelove (1972); Damodaran et al. (1975) and Yamaji et al. (2001), who concluded that citrinin at $125 \mathrm{ppm}$ caused collapse of the root structure and tissue browning, and the growth of seedlings was inhibited markedly .

\section{CONCLUSION:}

According to the obtained results, benzoic, sorbic acids and their ester forms especially ethyl benzoate are very effective in reducing the production of $\mathrm{AOH}$ and CTN by Alternaria alternate and Penicillium citrinum. The use of ethyl benzoate as alternative to the tested fungicides may realize a big challenge in reducing fungicides used for treatment of infected seedlings as spray. Besides, it reduces the phytotoxic effect of these mycotoxins which lead to diminish the virulence of these pathogens in field.

On the other hand, it was obvious that in order to avoid the failure of benzoic and sorbic acids and ethyl sorbate to realize best growth to the infected seedlings, further studies are needed on treatment of the infected seeds with metalaxyl $(x)$ or ridomil $M Z(x)$ before sowing seeds and reduction of the number of spraying time of seedlings with benzoic or sorbic acids or ethyl sorbate by spraying seedlings each 21 days instead of 15 days. 
Table (5): Effect of the tested treatments on certain plant growth parameters:

\begin{tabular}{|c|c|c|c|c|c|c|}
\hline Tested treatments & A & B & C & D & $\mathbf{E}$ & $\mathbf{F}$ \\
\hline Healthy control & 10ml St.w & $16.95 a$ & $8.049 a$ & $0.0 f$ & $0.000 \mathrm{e}$ & - \\
\hline Infected control & $10 \mathrm{ml} \mathrm{St.w}$ & $5.43 \mathrm{~cd}$ & $2.282 d$ & $15.4 a$ & $0.697 a$ & - \\
\hline Metalaxyl & $x$ & 3.40de & $3.177 \mathrm{~cd}$ & $12.90 a b$ & $0.462 b$ & 33.715 \\
\hline Metalaxyl & $1.5 X$ & $2.35 \mathrm{e}$ & $2.767 \mathrm{~cd}$ & $5.01 \mathrm{~cd}$ & $0.289 c$ & 58.536 \\
\hline Ridomil & $X$ & $7.40 \mathrm{c}$ & $4.71 b c$ & $10.860 b$ & $0.203 \mathrm{~cd}$ & 70.875 \\
\hline Ridomil & $1.5 X$ & $11.9 b$ & $6.085 a b$ & $4.660 \mathrm{~cd}$ & $0.0840 \mathrm{de}$ & 87.948 \\
\hline Ethyl benzoate & $5 p p m$ & $13.6 b$ & $6.460 a b$ & 3.00de & $0.0598 \mathrm{e}$ & 91.42 \\
\hline Ethyl benzoate & $10 \mathrm{ppm}$ & $6.1 \mathrm{~cd}$ & $4.383 \mathrm{bcd}$ & $4.700 \mathrm{~cd}$ & $0.118 \mathrm{de}$ & 83.070 \\
\hline Ethyl Sorbate & $5 p p m$ & $11.4 b$ & $3.770 \mathrm{~cd}$ & $4.800 \mathrm{~cd}$ & $0.105 \mathrm{de}$ & 84.935 \\
\hline Ethyl Sorbate & $10 p p m$ & $5.75 \mathrm{~cd}$ & $4.660 \mathrm{bc}$ & $5.100 \mathrm{~cd}$ & $0.268 c$ & 61.549 \\
\hline Benzoic acid & 10ppm & $6.26 \mathrm{~cd}$ & $3.803 \mathrm{~cd}$ & $1.500 \mathrm{ef}$ & $0.074 \mathrm{de}$ & 89.383 \\
\hline Benzoic acid & $15 \mathrm{ppm}$ & 4.6de & $3.310 \mathrm{~cd}$ & $5.00 \mathrm{~cd}$ & $0.495 b$ & 28.98 \\
\hline Sorbic acid & $10 \mathrm{ppm}$ & $11.05 b$ & $6.380 a b$ & $4.300 \mathrm{cde}$ & $0.100 \mathrm{de}$ & 85.653 \\
\hline Sorbic acid & $15 \mathrm{ppm}$ & 3.94de & $2.583 \mathrm{~cd}$ & $6.200 \mathrm{c}$ & $0.477 \mathrm{~b}$ & 31.563 \\
\hline L.S.D 0.05 & & 2.4209 & 1.89645 & 2.68199 & 0.11852 & \\
\hline
\end{tabular}

Where:

$A=$ Concentration of tested treatments.

$\mathrm{B}=$ Average of one seedling shoot length in $\mathrm{cm}$.

$\mathrm{C}=$ Average of Fresh weight ofone seedling

$\mathrm{D}=$ Black color lesions $(\mathrm{BCL})$ On shoot in $\mathrm{cm}$

$\mathrm{E}=\mathrm{BCL}$ ratio on shoot $=$ black lesions length $=\mathrm{A} v$ of lengths of black lesions on treated seedlings $/ \mathrm{Av}$ of total seedlings lengths $X=R . D=500 \mathrm{mg} / 250 \mathrm{ml}$ water.

$1.5 X=R . D+0.5 R . D=750 \mathrm{mg} / 250 \mathrm{ml} \&$ Seedling = complete growing plant but before flowering then fruiting stages. 
Table (6): Assessment of alternariol (AOH) and citrinin (CTN) in obtained plants after agriculture process and efficacy ratios (E.R \%) of treatments:

\begin{tabular}{|c|c|c|c|c|c|}
\hline Treatment & Tested conc. & $\begin{array}{l}\mathrm{AOH} \\
\mu \mathrm{g} / \mathrm{g}\end{array}$ & E.R.\% & $\begin{array}{c}\text { CTN\% } \\
\mu \mathrm{g} / \mathrm{g}\end{array}$ & E.R.\% \\
\hline Healthy cont. & 0.0 & $0.00000^{\top}$ & - & $0.0000^{g}$ & - \\
\hline Infected cont. & 0.0 & $219.739^{\mathrm{a}}$ & - & $250.95^{a}$ & - \\
\hline Metalaxyl & $\mathrm{X}$ & $142.150^{C}$ & 35.309 & $62.283^{d}$ & 85.859 \\
\hline Metalaxyl & $1^{1 / 2 X}$ & $199.013^{b}$ & 9.4320 & $68.138^{c}$ & 72.848 \\
\hline Ridomil MZ & $\mathrm{X}$ & $86.777^{d}$ & 60.509 & $81.676^{b}$ & 67.453 \\
\hline Ridomil MZ & $1^{1 / 2 X}$ & $45.489^{9}$ & 79.299 & $60.972^{\mathrm{d}}$ & 75.703 \\
\hline Sorbic acid & 10ppm & $80.9697^{e}$ & 63.152 & $2.1816^{\mathrm{tg}}$ & 99.131 \\
\hline Sorbic acid & $15 \mathrm{ppm}$ & $36.708^{\mathrm{h}}$ & 83.294 & $5.3810^{\mathrm{e}}$ & 97.856 \\
\hline Benzoic acid & $10 \mathrm{ppm}$ & $60.6515^{\dagger}$ & 72.398 & $4.4048^{\text {et }}$ & 98.245 \\
\hline Benzoic acid & $15 \mathrm{ppm}$ & $35.242^{h}$ & 83.962 & $3.9308^{\mathrm{et}}$ & 98.434 \\
\hline Ethyl sorbate & $5 \mathrm{ppm}$ & $39.195^{\mathrm{h}}$ & 82.163 & $4.0367^{\mathrm{et}}$ & 98.391 \\
\hline Ethyl sorbate & $10 \mathrm{ppm}$ & $24.0079^{\prime}$ & 89.074 & $4.1931^{\mathrm{ef}}$ & 98.329 \\
\hline Ethyl benzoate & $5 \mathrm{ppm}$ & $13.0401^{J}$ & 94.065 & $1.5724^{\mathrm{fg}}$ & 99.373 \\
\hline Ethyl benzoate & 10ppm & $6.6337^{k}$ & 96.981 & $1.4413^{\mathrm{fg}}$ & 99.426 \\
\hline L.S.D 0.05 & & 3.99945 & & 2.64552 & \\
\hline
\end{tabular}

\section{REFERENCES:}

Abd-EL-Ghany,T.M and A.A. Tayel. 2009. Efficacy of certain agrochemicals application at Field Rates on Soil Fungi and their Ultra- structures. Res. J. of Agriculture and Biological Sciences, 5(2):150-160.

Abou-Zeid, A. M. 2012. Review on Citrinin: Synthetic Methods, Molecular Biosynthesis and Effect of Plant Extracts. British Microbiology Research Journal ,2(2) 108-122.

Anand, S.P. and N. Sati. 2013. Artificial Preservatives and Their Harmful Effects: Looking Toward nature For Safer Alternatives. Res. J. of Agriculture and Biological Sci., 4(7): 2496-2501.

Asam ,S., K. Konitzer, P. Schieberle and M., Rychlik. 2010. Stable isotope dilution assays of alternariol and alternariol monomethyl ether in beverages. J Agric Food Chem, 57:5152-5160 .

Asam, A., K. Konitzer, M. Rychlik. 2011. Precise determination of the Alternaria mycotoxins alternariol and alternariol monomethyl ether in cereal, fruit and vegetable products using stableisotope dilution assays. Mycotox. Res., 27, 23-28.

Azcarate, M.P.,A. Patriarca, L. Terminiello, V.F.Pinto. 2008. Alternaria toxins in wheat during the 2004 to 2005 Argentinean harvest. J. of Food Protection, 71: 1262-1265.

Barkai-Golan, R., P. Nachman. 2008. Alternaria mycotoxins. In Mycotoxins in fruits andvegetables, Eds. Barkai-Golan, R.\& Nachman, P. Academic Press, San Diego, CA, USA, 185203. 
Battilani, P., L.G. Costa, A. Dossena, M.L. Gullino ,R. Marchelli, G.Galaverna, A. Pietri, C. Dall'Asta, P. Giorni, D. Spadaro, A. Gualla. 2009. Scientific information on mycotoxins and natural plant toxicants, Scientific/Technical report submitted to EFSA, 8214 (10).

Bensassi, F., M. Zidi, A. Rhouma, H. Bacha, M.R. Hajlaoui. 2009. First report of Alternaria species associated with black point of wheat in Tunisia, Annals of Microbiology, 59 (3), 465467.

Bhaat, R. V.,R.V. Rai, A.A. Karim. 2010. Mycotoxins in food and feed: present status and future concerns, comprehensive reviews in Food Science and Food Safety, J. of Food Protection,9: 57-81.

Bhatnagar ,.D.,E.B. Lillehoj, ,J.W. Bennett. 1991. Biological detoxification of mycotoxins. In: Smith, JE, Henderson, RS, eds. Mycotoxins and Animal Foods, Boston: CRC Press, 816-826.

Brzonkalik,.K.T.,Herrling,C. Syldatk and A.Neumann. 2011. The influence of different nitrogen and carbon Sources on mycotoxin production in Alternaria alternata. Int. J. Food Microbiol., 27:147(2):120-126.

Bodroža-Solarov, M., J. Brkljača,J. Vučković, F. Balaž. 2012. Changes in technological quality of winter wheat with different intensity of Fusarium spp. and Alternaria spp. contamination. In Proceedings of 15th International Feed Technology Symposium, FEED-ToFood/Cost FeedFor Health Joint- Workshop, Novisad, Serbia , 366-370.

Burkin, A.A. and G.P Kononenko. 2011. Enzyme immunoassay of alternariol for the assess mentof risk of agricultural products contamination. Applied Biochemistry and Microbiology, 47, 72-76.

Christensen, C.M. 1957. Determination of stored grains by fungi. Botan. Res., 108-134.

Cohen. E. 1981. Metalaxyl for postharvest control of of brown rot of citrus fruit. Plant Disease, 65: 672-675.

Damodaran, C., S. Kathirvel-Pandian ,S. Seeni., R. Selvam M.G. Ganesan, S. Shan -mugasundaram. 1975. Citrinin, a phytotoxin? Experientia ,31: 1415-1417.

Deepavali,S. D. and W.K. Nilima. 2012. Effect of aflatoxin on germination and seedling growth . Archives of Applied Sci. Res., 4 (6):2441-2446

Dixit.S,and S.Singh. 2003. Effect of organic acids and food preservatives on fumonisins (FB1 and FB2) by Fusarium moniliforme. Food Addit. Contam.,20(5):490-3.

Eckhout, M., S.Ladschoot, N.,Deshuyffeleer, S.De Laethauwer and G.Haesaert .2013. Guidelines for prevention and control of mould growth and mycotoxin production in cereals.pp37.

El Morsy, E.M., S.M. Dohlob, and K.D.Hyde. 2006.Diversity of Alternaria alternata a common destructive pathogen of Eichhornia crassipe in Egypt and its potential use in biological control.Fungal Diversity .,23:139-158.

EI Wakil, M.A.,M. El Refai,O.A. Awadalla,M.A.,El Metwally and M.S.Mohammed. 2009. Seed-Borne Pathogens of Faba Bean in Egypt: Detection and Pathogenicity .J. of Plant pathol.,8(3): 90-97.

Embaby,E.M.,M.Hazaa,L.F.Hagag,T.E.S., Ibrahim and F.S. Abd El-Azem. 2013. Decay of Some Citrus Fruit Quality Caused by Fungi and their 
Control: II- Control Alternaria rot or core rot decay by using some alternative fungicides. Journal of Applied Sci. Res., 9(11): 5671-5678.

European Food Safety Authority. (EFSA). 2011. Panel on Contaminants in the Food Chain: Scientific opinion on the risks for animal and public health related to the presence of Alternaria toxins in feed and food. EFSA $J, 9$ : 2407 .

Frisvad, J. C., T. O. Larsen, R. DeVries, M. Meijer, M. J. Houbraken, F.J. Cabanes, K. Ehrlich and R.A. Samson .2007. Secondary metabolite profiling, growth profiles and other tools for species recognition and important Aspergillus mycotoxins. SIM, 59: 31-37.

FLRP.2004. Food Legume Research Program. Nile and Red Sea Regional Program. National coordination meeting, Cairo, Egypt.

Fern'andez-Cruz, M.L.,M.L. Mansilla, J.L. Tadeo. 2010. Mycotoxins in fruits and their processed products: Analysis, occurrence and health implications. Journal of Advanced Research, 1: 113-122.

Friedman M. and R. Rasooly .2013.Review of the inhibition of biological Activities of Food-Related selected Toxins by Natural Compounds. Toxins (Basel), 5(4): 743-775.

Fujita,H. and K.Syono.1996. Genetic Analysis of the Effects of Polar Auxin Transport Inhibitors on Root Growth in Arabidopsis thaliana .Plant Cell Physiol., 37(8): 1094-1101.

Hawthorne,W.,T. Bretag,M. Raynes,J. Davidson,R. Kimber,S.A. Sardi, A. Nikandrow,P. Matthews andJ. Paull .2014. Faba Bean Disease Management Strategy for Southern Region GRDC 2004.Faba bean -mgtBrochure pp4. Pulse Australia.

Hertel, R., M.L. Evans, A.C. Leopold and H.M. Sell. 1969 .The specificity of the auxin transport system. Planta, 85: 238-249v.

Hertel, R., T.L. Lomax, and W.R. Briggs. 1983. Auxin transport in membrane vesicles from Cucurbita pepoL. Planta,157: 193-201.

International Seed Testing Association (ISTA). 1996. International rules for seed testing. Proc. Int. SeedTest. Assoc. Zurich, Switzerland.

ICARDA .2005. Faba bean pathology progress report 2003/04. Food Legume Improvement Program, ICARDA, Aleppo., Syria.p.9.

Javaid, A., A. Ashraf, N. Akhtar, M. Hanif and M. A. Farooq. 2006. Efficacy of some fungicides against seed-borne mycoflora of wheat. Mycopath., 4(1): 45-49

Jouany.J.P.(2007). Methods for preventing, decontaminating and minimizing the toxicity of mycotoxins in feeds. Animal Feed Science and Technology, 137: 342-362.

Khan ,S.A, M. Hamayun,H. Yoon,H.Y. Kim, S.J. Suh, S.K. Hwang, J.M. Kim ,I.J. Lee, Y.S., Choo, U.H. Yoon, W.S., Kong, B.M. LeeJ.G. Kim. 2008. Effects of Penicillium extracts on germination, vigour in subsequent seedling growth of tomato (Solanum lycopersicum L.). Archives of Phytopathology and Plant Protection, 01/2011; DOI: 10.1080/03235408.2011.603965.

Kim,S.A. and K.S. Roh.2014. Effect of p-Coumaric Acid, Benzoic Acid, and Salicylic Acid on the Activity of Glutathione Reductase and Catalase in in 
vitro Grown Tobacco Plants. J.of Life Science. (24): 3: 227-233, DOI : http://dx.doi.org/10.5352/JLS.2014.24.3.227

Kosiak, B., M.Torp, E. Skjerve, B. Andersen.2004 . Alternaria and Fusarium in Norwegian grains of reduced quality - a matched pair sample study. Int J Food Microbiol, 93: 51- 62.

Kütt, M. L., Liveke, H., Tanner, R. (2010). Detection of alternariol in Estonian grain samples. Agronomy Research, 8, II: 317-322.

Lugauskas, A. 2005. Potential toxin producing micromycetes on food raw material and products of plant origin. J. Botanica lithuanica , 7: 3-16.

Maffei, M., C.M. Bertea, F. Garneri and S. Scannererini.1999. Effect of benzoic acid hydroxyl and methoxy ring substuents during cucumber (Cucumis sativus L.) germination. Isocitrate lyase and catalase activity. Plant Sci., 141:139-47.

Magarey, R.C. and J.I. Bull.1994. The control of yield decline in sugarcane with fungicides. Plant Protection Quarterly, 9: 90-93.

Magarey, R.C. and B.J. Croft. 1995. A review of root disease research in Australia. Proc. Int. Soc. Sugar Cane Technol., 22: 505-513.

Magarey, R.C., H.Y. Yip, J.I. Bull and E.J. Johnson.1995. Recent Studies into the soil biology of yield decline. Proc. Aust. Soc. Sugar Cane Technol., 17: 128-133.

Magarey, R.C., H.Y., Yip, J.I. Bull, and E.J. Johnson.1997. Effect of the fungicide mancozeb on fungi associated with sugarcane yield decline in Queensland. Mycological Research, 101: 858-862.

Magarey, R.C. and J.I .Bull. 2003. Effect of the dithiocarbamate fungicide mancozeb on sugarcane growth and soil biology in yield decline affected soils.J.of Proc. Aust. Soc. Sugar Cane Technol., Vol. 25.

Matheron, M. E. and M. Porchas. 2000. Comparative Effect of Five Fungicides on the Development of Root and Stem Rot and Survival of Chile Pepper Plants Grown in Field Soil Naturally Infested with Phytophthora capsici. University of Arizona College of Agriculture 2000 Vegetable Report, index at http://ag.arizona.edu/pubs/crops/az1177/ ether on flavedo and albedo tissues of tangerines (Citrus reticulata)

Malachova, A., Z. Dzuman, Z.Veprikova, M. Vaclavikova,M. Zachariasova and J. Hajslova. 2011. Deoxynivalenol, deoxynivalenol-3-glucoside, and enniatins: The major mycotoxins found in cereal-based products on the Czech market. J Agric Food Chem., 59:12990-12997.

Maškova , Z., D. Tančinova, Z., Barborekova, S. Felšciova, M. C'ı́sarov'a. 2012. Comparison of occurrence and toxigenity of Alternaria spp. isolated from samples of conventional and new crossbread wheat of Slovak origin. Journal of Microbiology Biotechnology and Food Sciences, 1: 552-562.

Maalouf,F., A. Hamdi, J.r. Cubero, G.E. Khalifa, M. Jarsso, S.K. Kemel. 2009. Development of Faba bean productivity and production in the Nile valley ,Red sea and Sub saharan region.Icarda,Aleppo,Syria.

Maouni, A., A. Lamarti,A. Badoc,A. Douira .2002. Étude de la résistanced'Alternaria alternata et de penicillium expansum aux fongicides lors de la conservation des poires. Bull. Soc. Pharm. Bordeaux, 141: 6172.

McDonald, J.H. 2009. Handbook of Biological Statistics,[ 2nd ed.] pp.291 Sparky House Publishing, Baltimore, Maryland. 
Miller, J.D., J.C. Young, H.L. Trenholm.1983. Fusarium toxins in field corn. I. Time course of fungal growth and production of deoxynivalenol and other mycotoxins. Can. J .Bot., 61:3080-3087.

Mohamed, Z.R.,Y.Honda,Z.I.Sayed,N.Muroguguchi and S.Arase.2002. Leaf spot Disease of Broad Bean( Viccia faba L) caused by Alternaria tenuissina A new disease in Japan. J. of General Plant Pathology, 68:1:31-37.

Moradi ,D. P., F. Sharif-zadeh, M.Janmohammadi. 2008. Influence of priming techniques on seed germination behavior of maize inbred lines (Zea mays L.) ARPN. Journal of Agricultural and Biological Sci., 3(3): 22-25.

Muller,H.M., R. Amend.1997. Formation and disappearance of mycophenolic acid, patulin, penicillic acid and PR toxin in maize

silage inoculated with Penicillium roqueforti. Arch Tierernahr,50:213-225.

Nickell L.G.and A.C. Finlay.1954. Antibiotics and their effects on plant growth. Journal of Agricultural and Food Chemistry, 2: 178 -182.

Perell, A. 2010a. New and emerging fungal pathogens associated with leaf blight symptoms on wheat (Triticum aestivum L.) in Argentina. 2010. In: Management of Fungal Plant Pathogens. (Eds.): A. Arya \& A. Perell. CAB International, United Kingdom, Chapter 18: 231-243.

Perell., A . 2010b. Alternaria leaf blight. In: Compendium of wheat Diseases and Pests. Third Edition, 2010. pp. 16-17.

Published by APS (American Phytopathological Society) St.Paul, Minnesota, USA.

Perello, A., R. Labuda and M. Sulyok. 2012. Pathogenicity and toxins of Altenaria species-groups on wheat in Argentina. $5^{\text {th }}$ International Meeting of Mycotoxicology, 3-4December 2012, Milan, Roma.

Perell., A., V. Moreno and M. Sisterna. 2008. Alternaria infectoria speciesgroup associated with black point of wheat in Argentina. Plant Pathology, 57: 379.

Perell., A., V. Moreno, M. Sisterna and A.M. Castro. 2005. Occurrence and characterization on wheat of the Alternaria infectoria complex associated with black point and leaf blight symptoms in Argentina. $7^{\text {th }}$ Internacional Wheat Conference. Nov. 27-Dec 2, 2005. Mar del Plata, Argentina. Organized by SAGPyA and INTA. ,pp.149.

Perelló,. A. E. and S. Iarrán .2013. Nature and effect of Alternaria spp. complex from Wheat grain on germination and disease transmission. Pak. J. Bot., 45(5): 1817-1824.

Pitt,J. and A.D. Hocking. 1997. Fungi and food spoilage. NewYork, Blackic Academic \&professional.

Rajput, M.A., M.A. Pathan, A.M. Lodhi, G.S. Shah and K.A. Khanzada. 2005. Studies on seed-borne fungi of wheat in Sindh Province and their effect on seed germination. Pak. J. Bot., 37(1): 181-185.

Samson, R. A., E. S. Hoekstra, J. C. Frisvad and O. Filtenborg. 1996. Introduction to food-borne fungi (6th edition), central bureau voor schimmel cultures, Baarn, The Netherlands.

Saleem, A. R. 2010. Effect of Kocide and Ridomil MZ plus fungicides on the mycoflora of tomato plant in Upper Egypt. Archives Of Phytopathology And Plant Protection, 43: 17: 1658-1675. 
Saleem, M.J., R .Bajwa., Q. Abdul Hannan, and T.A. QAISER. 2012. Maize seed storage mycoflora in pakistan and its chemical control . Pak. J. Bot., 44(2): 807-812.

Sarmamy, A .G.O.I. and S.M. Khidir. 2013. Effects of some soil treated pesticides on growth characteristics of Faba bean and Wheat plants. International Association of Scientific Innovation and Research (IASIR), 1:14.

Scott ,S.J, R.A. Jones, W.A. Williams. 1984. Review of data analysis methods for seed germination. Crop Sci., 24: 1192-1199.

Shu-Yuan Cheng, S. O.H .S., M. T.A. C. Velasco,J. Montalvo and A.Calderone.2014. RTP801 Regulates Maneb- and Mancozeb-Induced Cytotoxicity via NF-kB. J. of Biochemical and Molecular Toxicology. DOI: 10.1002/jbt.21566. Wiley Periodicals, Inc.

Singh,H. and. R.H. Garampalli. 2012. Screening of plant extracts for organic management of downy mildew of sorghum. Archives of Phytopathology and Plant Protection, 45: 1732-1740.

Sitara, U. and N. Hasan . 2011. Studies on the efficacy of chemical and nonchemical treatments to control mycoflora associated with chilli seed. Pak. J. Bot. 43(1): 95-110.

Sitara, U. and S. Akhter. 2007. Efficacy of fungicides, sodium hypochlorite and neem seed powder to control seed borne pathogens of maize. Pak. J. Bot., 39(1): 285-292.

Soughir, M., E.M. Aymen and H. Cherif .2012. Effect of NACL Priming Duration and Concentration on Germination Behavior of Fenugreek Albanian J. Agric. Sci., 4 (11): 2218-2020.

Suchowilska,. E., W. Kandler, M. Sulyok and K.R. Wiwart. 2010. Mycotoxin profiles in the grain of Triticum monococcum, Triticum dicoccum andTriticum spelta after head infection with Fusarium culmorum. J.Sci.Food Agric, 90:556-565.

Sunaina, N., B. Singh. 2014. Mitigating effect of activated charcoal against allelopathic stress . Biolife J., 2(1):407-414.

Torres,A.M.B.,C.M.Román,Z.Avila,D.Satovic,J.C..,Rubiales.I.,Sillero,O.J.Cu ber andM.R. Moreno.2006a. Faba bean breeding for resistance against biotic stress towards application of marker technology.Euphytica,147(12):67-80.

U.S.Salinity Laboratory Staff. 1954. Diagnosis and improvement of saline and alkali soil U.S. Dept. Agric. Hand book № 60,1609

Vučković.J.,J.S. Brkljača.,M.I. Bodroža-Solarov,F.F. Bagi,V.B. Stojšin, J.N Ćulafić,M.G. Aćimović. 2013. Alternaria spp. on small grains UDC 633.1: [632.26+632.4]Review paper edit.by project III46005 "Novi proizvodi cerealija i pseudocerealija iz organske proizvodnje" ("New products based on cereals and pseudo cereals from organic production").

Vučković, J., F.Bagi, M., Bodroža-Solarov,V. Stojšin, D. Budakov, V. Ugrenović, M. Aćimović 2012. Alternaria spp. on spelt kernels (Triticum aestivum spp. spelta). Plant Doctor, 1: 50-55.

Wandrey, L.L., K.E .Grice, R.A. Peterson and J.De Faveri.2004. The use of metalaxyl and potassium phosphonate,mounds,and organic and plastic mulches, for the management of Phytophthora root of Papaya in far northern Queensland. Australasian Plant Pathology, 33:103-107.

Wang, F.H. 1948. The effects of clavacin upon root growth. Botanical Bulletinof Academia Sinica ,2: 265 -269. 
White, A.G and B. Truelove. 1972. The effects of aflatoxin B1, citrinin, and ochratoxin A on amino acid uptake and incorporation by cucumber. Canadian Journal of Botany ,50: 2659 -2664.

Yadav,K. and N.B.Singh.2013. Effects of benzoic acid and cadmium toxicity on wheat seedlings. Chilean Journal of Agricultural Research, 73(2) :723734.

Yamaji,.K., Y .Fukushi, Y. Hashidoko,T. Yoshida and S. Tahara.2001. Penicillium fungi from Picea glehnii seeds protect the seedlings from damping-off. J.of New phytologist, 152: 521-531.

Yehia A.-G.M., N.M. Abou El Souod, S. Alsokari,I. Abd-Elwahb,A. Magid and K. E. Mohsen .2011. Recent approaches for controlling brown spot disease of Faba Bean in Egypt. Egypt Acad. J. biolog. Sci., 3(1): 41- 53 .

Youssef, N.H., I. A. El Samra., A. I. Abdel Bary.2014. Effect of benzoic and sorbic acids on mycotoxins inhibition in edible broad bean seeds. J. Of The Advances In Agricultural Researches , 19 (3): 482- 498.

Zeidan,E.H.E. 2006.Effect of Menno-Florades on Microflora of Grapevine phyllosphere and their Antagonistic Potential on Plasmpara viticola. Research J. of Agriculture and Biological Sciences, 2(6): 262-267.

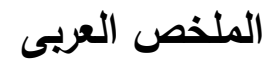

حل بديل للتحكم فى انتاج كل من السترينين والالترناريول على محصول الفول البلدي

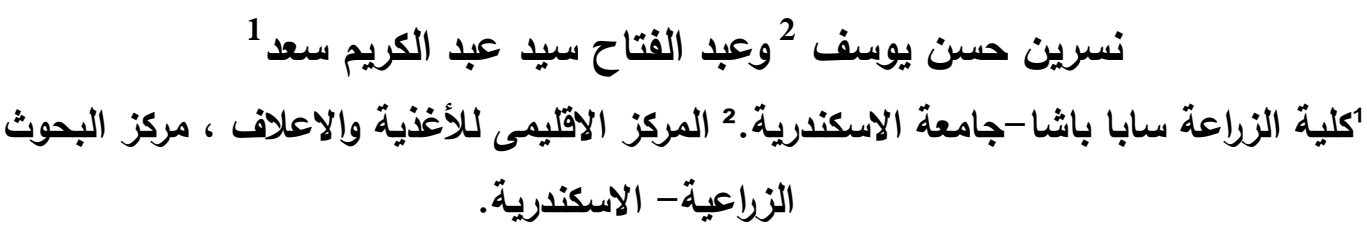

استهدفت الاراسة عدة نقاط : الماط اولا : دراسة تطوركل من المرض الفطرى ( والحادث لاول مرة فى منطقة النوبارية ) وانتاج السمين الفطريين تحت

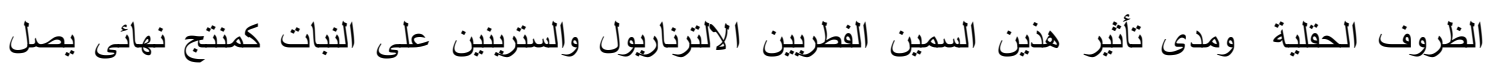
للسلسلة الغذائية للانسان. ثانيا: دراسة تأثير المبيدات الميتالاكسيل والريدوميل والتى كانت تستخدم لوقاية البذور والنباتات السليمة من

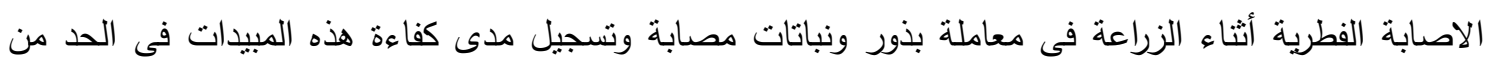
الاصابة وتقليل انتاج التوكسينات.

ثالثا: دراسة تأثير كل من حمضى السوربيك و والبينزويك والاستر الخاص بكل منهما على كل من النبات والتوكسينات المنتجة أثثاء الزراعة ودراسة مدى كفاءة هذه المواد كبدائل امنة لتقليل الجرعات المستخدمة من المبيد

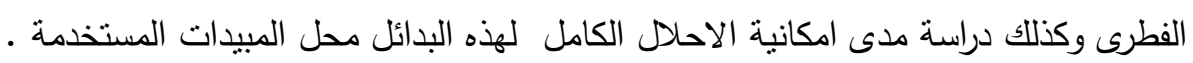


ولقد توصل البحث إلى النتائج التالية : - نم تطبيق طريقة المعاملة بالرش للبادرات كل 15 يوم لفشل الاحماض

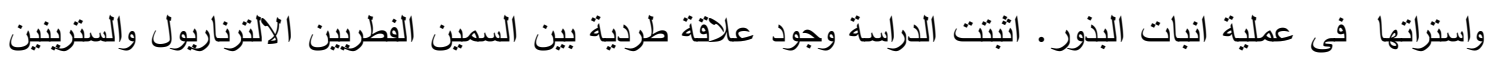

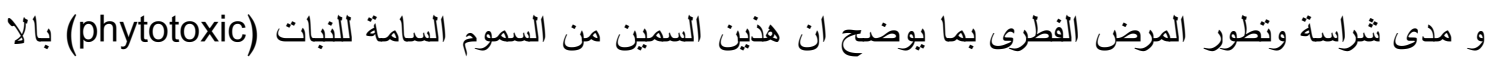
ضافة لكونهاسموم عصبية (nephrotoxic) وسموم خلوية (cytotoxic) ومسرطنة ايضا (carcinogenic) للانسان والحيوان على حد سواء ـكما اثتت الدراسة وجود نوع من التعاضد بين الفطرين وماينتجانه من سموم فى لى التأثثر على حجم المناطق السوداء التى تظهر على النباتات المصابة فقط وتقل بعد المعاملات محل الدراسة

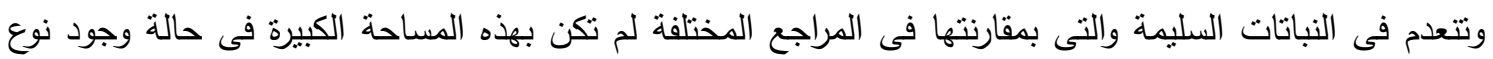
واحد من السموم المختبرة وتتعدم فى حالة الاصابة بسلالة فطرية غير قادرة على انتاج ایى من السمين.

أظهرت الدراسة تأثنركل من المبيدات المستخدمة و الاحماض العضوية والاسترالخاص بكل منها على كل من

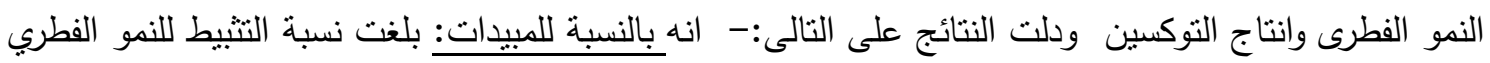

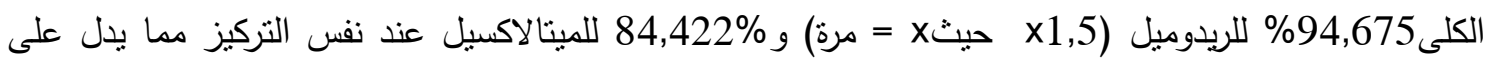
تقوق الريدوميل على الميتالاكسيل عند نركيز (1,5 مرة قدر النسبة المقررة لرش البادرات فى حالة الوقاية) كما قلل الريدوميل( عند نفس التركيز المذكور) نسبة الموت للبادرات بنسبة 61,11\% . بالنسبة لحمضى البنزويك

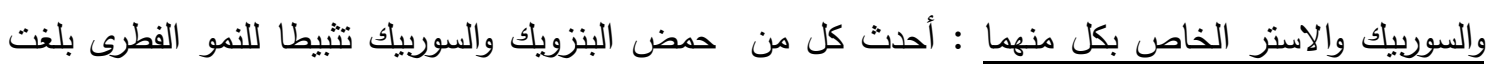
بسبته 100\% 97,36\% على التوالى وذلك عند نركيز 15 جزء فى المليون بينما حقق كل من ايثايل بنزويت وايثايل سوربيت 100\% نتبيطا للنمو الفطرى عند نركيز5 جزء فى المليون كما بلغت نسبة الخفض في المناطق

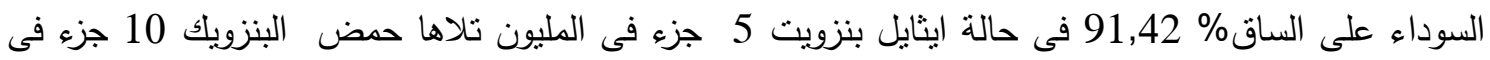

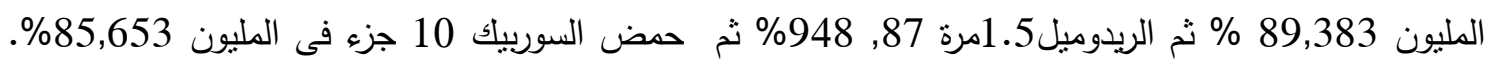
أظهرت الدراسة أن الأحماض المستخدمة واستراتها كانت أكثر كفاءة فى القدرة على تثيط وخفض انتاج التوكسين فى النبات النامى تحت الظروف الحقلية حيث بلغت نسبة خفض السترينين 99,426 \% 99,373\% بواسطة ايثايل البنزويت على التركيزين 5 و 10 جزء فى المليون على التوالى تلاه حمض السوربيك على تركيز 10 جزء

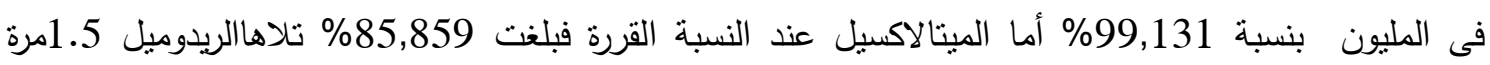
للنسبة المقررة 75,703\% . فى حالة السم الفطرى الالترناريول كا ن المركب ايثايل بنزويت هو الاكثر كفاءة فى

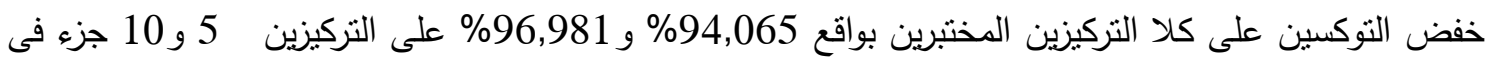

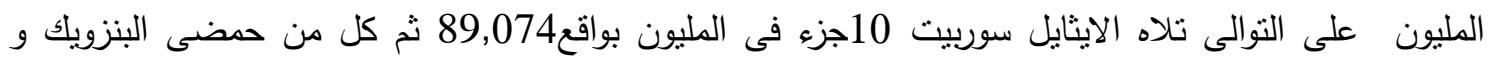
السوربيك 15جزء فى المليون بفاعلية تنبط 83,962\% و 83,294\% على التوالى. كانت نتائج المبيدات أقل فئل فاعلية من البدائل محل الاختبار فى قدرتها على تثبيط انتاج الالترناريول حيث بلغ اقصى تثنيط للريدوميل

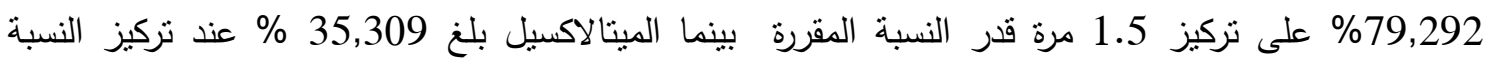
المقررة (x) مما يدل على عدم حساسية الالترناريول للميتالاكسيل . التوصيات: نوصى باستخدام الميثايل بنزويت كبديل للمبيدات الفطرية فى حالة الرش وذللك بعد اجراء مزيد من

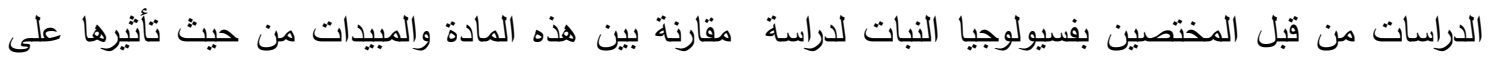
الخواص الفسيولوجية و الانتاجية للنبات. 
